\title{
De medische opleiding en de bachelor-masterstructuur
}

Hoe moet de medische opleiding er rond 2020 uitzien? Het Project Medisch Opleidingscontinuüm, ook wel het project 'de arts van straks' genoemd, gestart in mei 2001, richt zich op een toekomstverkenning voor de opleiding, vanaf vwoniveau tot het eind van de specialisatie. Het project wordt uitgevoerd als een samenwerking tussen de faculteiten, de Koninklijke Nederlandse Maatschappij tot bevordering der Geneeskunst (KNMG) en het Landelijk Centrum voor Verpleging en Verzorging, in een structuur van zes werkgroepen met elk zo'n acht deelnemers van verschillend pluimage. Er is, opzienbarend genoeg, onlangs een redelijk samenhangend tussenrapport verschenen en eind 2002 wordt een eindrapport verwacht, een jaar eerder dan gepland. Daarin speelt de actualiteit van de politiek mee: de minister van Volksgezondheid, Welzijn en Sport verwacht zo snel mogelijk een heldere beschrijving hoe het continuüm korter kan, zodat knelpunten in de zorg kunnen worden opgelost; de minister van Onderwijs, Cultuur en Wetenschappen wil weten hoe de medische opleidingen in de bachelor-masterstructuur moeten worden ingepast, want zij lopen achter op de rest van het hoger onderwijs.

Dit laatste is voor curriculumontwikkelaars interessant. Bij de discussies of een universitaire masteropleiding nu één of twee jaar moet duren zullen velen zich hebben afgevraagd hoe dat zou moeten voor de artsopleiding. De conceptwet over de BaMa-structuur spreekt echter al over een drie-plus-driejarige medische opleiding, uitgaande van de Europese richtlijnen die een zesjarige minimumduur voorschrijven.

Het rapport nu stelt voor om in Nederland naast elkaar twee modellen voor de artsopleiding te laten bestaan: één model dat erg lijkt op de huidige opleiding en één model van een vierjarige masteropleiding, waartoe een niet-medische bacheloropleiding toegang zou moeten kunnen verschaffen. De onderstaande figuur is een beknopte weergave van het voorstel.

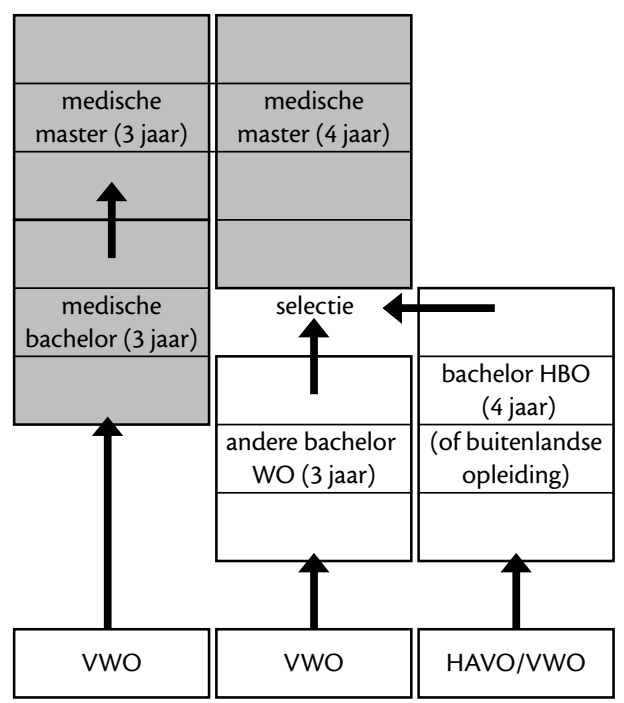

De redenering erachter is simpel. Een zesjarige opleiding verdelen in een bacheloren masterfase is vooral cosmetisch. De 
medische opleidingen zijn zo geïntegreerd dat een echte splitsing, bijvoorbeeld in een driejarige preklinische en een driejarige klinische fase, gelijk staat aan het terugdraaien van de klok van de ontwikkeling van het medisch onderwijs met vele jaren. Die integratie maakt ook doorstroming logisch voor alle studenten in dezelfde opleiding. Het label 'bachelor' en 'master' kan natuurlijk worden gegeven, maar heeft hier weinig praktische betekenis.

Wil men werkelijk het doel van de BaMa-gedachte bereiken, namelijk uitwisseling over opleidingen, nationaal en, bij voorkeur, internationaal, dan valt niet te ontkomen aan (a) een langere duur van de masteropleiding en (b) selectie voor de poort van deze opleiding, waarbij getoetst wordt op de voorkennis. Pas dan is het mogelijk een diversiteit van medisch getinte bachelors (ook uit het hbo!) in vier jaar dokter te laten worden.

Faculteiten zouden beide typen opleidingen kunnen aanbieden: ongedeelde opleidingen en vierjarige medische masteropleidingen tot arts. Dit past misschien niet precies in de huidige conceptwetgeving, maar als de overheid bereid is een vierjarige medische masteropleiding te accepteren - in feite een model dat sterk lijkt op de Noord-Amerikaanse opleiding tot arts - dan zijn er misschien interessante mogelijkheden voor internationale uitwisseling en harmonisatie, en daar was het allemaal immers om te doen.

Olle ten Cate 